\title{
Classification of Rhizomonas suberifaciens, an Unnamed Rhizomonas Species, and Sphingomonas spp. in rRNA Superfamily IV
}

\author{
ARIENA H. C. VAN BRUGGEN, ${ }^{1 *}$ KENNETH N. JOCHIMSEN, ${ }^{1}$ EVA M. STEINBERGER, ${ }^{1}$ \\ PAUL SEGERS, ${ }^{2}$ AND MONIQUE GILLIS ${ }^{2}$ \\ Department of Plant Pathology, University of California, Davis, California 95616, ${ }^{1}$ and \\ Laboratorium voor Microbiologie, Universiteit Gent, Ghent, Belgium ${ }^{2}$
}

\begin{abstract}
Thermal melting profiles of hybrids between ${ }^{3} \mathrm{H}$-labeled rRNA of Rhizomonas suberifaciens, the causal agent of corky root of lettuce, and chromosomal DNAs from 27 species of gram-negative bacteria indicated that the genus Rhizomonas belongs to superfamily IV of De Ley. On the basis of the melting temperatures of DNA hybrids with rRNAs from the type strains of $R$. suberifaciens, Sphingomonas paucimobilis, and Sphingomonas capsulata, Rhizomonas strains constitute a separate branch in superfamily $\mathrm{IV}$, which is closely related to but separate from branches containing Zymomonas mobilis, Sphingomonas spp., and $S$. capsulata. Sphingomonas yanoikuyae and Rhizomonas sp. strain WI4 are located toward the base of the Rhizomonas rRNA branch. DNA-DNA hybridization indicated that $S$. yanoikuyae is equidistant from Rhizomonas sp. strain WI4 and $S$. paucimobilis. Sequences of 270 bp of $16 S$ ribosomal DNAs from eight strains of Rhizomonas spp., eight strains of Sphingomonas spp., and Agrobacterium tumefaciens indicated that $S$. yanoikuyae and Rhizomonas sp. strains WI4 and CA16 are genetically more closely related to $R$. suberifaciens than to Sphingomonas spp. Thus, $S$. yanoikuyae may need to be transferred to the genus Rhizomonas on the basis of the results of further study.
\end{abstract}

Rhizomonas suberifaciens was described recently (27) as the causal agent of corky root disease of lettuce in California (24), Florida $(5,23)$, Wisconsin, and New York (23). At the present time, $R$. suberifaciens is the only species in the genus Rhizomonas. However, strains causing corky root of lettuce have been isolated from samples from Wisconsin, California, and The Netherlands, which indicates either that the species is relatively heterogeneous or that other species produce the same disease in lettuce $(25,26,27)$.

One of the strains that probably belongs to a different species of the genus Rhizomonas is strain WI4, which has a yellow pigment (absent in $R$. suberifaciens), a wider sugar utilization pattern, and a higher $\mathrm{G}+\mathrm{C}$ content than $R$. suberifaciens (63 mol\%, compared with $59 \mathrm{~mol} \%$ for $R$. suberifaciens) and which exhibits a relatively low level of DNA-DNA hybridization with the type strain of $R$. suberifaciens (27). This strain was considered to be a member of an unnamed Rhizomonas species closely related to Sphingomonas paucimobilis (formerly Pseudomonas paucimobilis) (13, 27, 29). Another strain, strain CA16, which was isolated from lettuce roots in California but was not pathogenic to lettuce, exhibited 70\% DNA homology with strain WI4 under moderately stringent conditions and probably belongs to the same Rhizomonas species (26). Strains CA16 and WI4 were also grouped into one cluster on the basis of fatty acid profiles (25).

The genus Sphingomonas was described at about the same time as the genus Rhizomonas with four named species in addition to the type species, $S$. paucimobilis $(27,29)$. $S$. paucimobilis was originally isolated from human clinical specimens and hospital environments (13) but later was also found in the rhizospheres of plants (2). $R$. suberifaciens and $S$. paucimobilis have many morphological, physiological, and biochemical characteristics in common $(13,27)$; the most important characteristic is a relatively large proportion

\footnotetext{
* Corresponding author.
}

of 2-hydroxylated myristic acid in the whole-cell fatty acid profiles $(6,14,27,29)$. However, there are some important differences between these species. $S$. paucimobilis has a much wider sugar utilization pattern, grows at a higher temperature, and is not pathogenic to lettuce (27). Moreover, the $\mathrm{G}+\mathrm{C}$ content of $S$. paucimobilis chromosomal DNA is $6 \mathrm{~mol} \%$ higher than the $\mathrm{G}+\mathrm{C}$ content of $R$. suberifaciens chromosomal DNA (27). Despite these differences between $S$. paucimobilis and $R$. suberifaciens, it was suggested that $S$. paucimobilis may belong to the genus $R$ hizomonas on the basis of the similarity in fatty acid compositions and the relatively high level of DNA-DNA homology between $S$. paucimobilis and strain CA1 of $R$. suberifaciens (27).

Both Rhizomonas and Sphingomonas species contain ubiquinone Q10 in their membranes (27). Isoprenoid quinones are characteristic for the higher groupings of bacteria (4). With the exception of the genus Acetobacter, which has ubiquinones Q8 and Q9 in addition to ubiquinone Q10 (4), the presence of ubiquinone $\mathrm{Q} 10$ as the main isoprenoid quinone seems to be restricted to rRNA superfamily IV (27) as defined by De Ley and coworkers (9-11). As used in this study, rRNA superfamily IV corresponds to the alpha group of the Proteobacteria as defined by Stackebrandt et al. (21). Because of the importance that can be attached to quinone analysis, it is likely that $R$. suberifaciens also belongs to superfamily IV (27).

$S$. paucimobilis and Sphingomonas capsulata belong to a single rRNA cluster in rRNA superfamily IV (3). The genus Zymomonas, a genus containing ethanol-producing bacteria isolated from palm wine, represents another rRNA branch in this cluster (12). Since $R$. suberifaciens seems to be related to $S$. paucimobilis, these organisms could belong to the same branch or closely related branches of rRNA superfamily IV.

The objectives of this study were to determine whether the genus Rhizomonas belongs to superfamily IV and to study the relationships among the genera Rhizomonas, Sphingomonas, and Zymomonas. 


\section{MATERIALS AND METHODS}

Bacterial strains. All of the strains which we used are shown in Table 1. Agromonas oligotrophica ATCC 43045 was included because it contains ubiquinone Q10 and probably belongs to superfamily IV (19). Pseudomonas fluorescens ATCC $13525^{\mathrm{T}}(\mathrm{T}=$ type strain), Pseudomonas syringae pv. syringae Kado 5D4214, and Xanthomonas campestris pv. campestris Kado 2D511 were included as representatives of superfamily II, and Pseudomonas cepacia Kado 23D4 was included as a representative of superfamily III (11). Strains WI4 and CA16, which are members of an unnamed Rhizomonas species distinct from $R$. suberifaciens $(26,27)$, were included to determine their relationships with $S$. paucimobilis and $S$. capsulata.

Most strains were cultured in S medium broth (24) for 2 days at $28^{\circ} \mathrm{C}$ with shaking. Cultures of $R$. suberifaciens and Agromonas oligotrophica strains were grown for 4 days and 1 week, respectively. Cultures of strains assigned to the genera Sphingomonas and Zymomonas were grown either on $\mathbf{S}$ medium or as described previously $(9,12)$. Beijerinckia indica ATCC 9039 was cultured in American Type Culture Collection (ATCC) medium 13 (1), Xanthobacter autotrophicus ATCC 35674 was cultured in nutrient broth, and Gluconobacter oxydans subsp. sphaericus ATCC 33280 was grown in ATCC medium 1.

DNA-rRNA hybridization. Thermal melting profiles were determined for hybrids between ${ }^{3} \mathrm{H}$-labeled $16 \mathrm{~S}$ and $23 \mathrm{~S}$ rRNAs from $R$. suberifaciens $\mathrm{CA}^{\mathrm{T}}, S$. paucimobilis LMG $1227^{\mathrm{T}}$, and $S$. capsulata LMG $2830^{\mathrm{T}}$ and DNAs from the strains listed in Table 1.

DNA was isolated as described by van Bruggen et al. (27) and was applied to nitrocellulose filters (diameter, $47 \mathrm{~mm}$; type 11358; Sartorius) under a vacuum (8). Filters containing DNA were stored under a vacuum at $4^{\circ} \mathrm{C}$. To calculate the size of disc needed for hybridization $(50 \mu \mathrm{g}$ of DNA per disc), 10-mm-diameter discs were punched out, incubated overnight at $50^{\circ} \mathrm{C}$ in $2 \times \mathrm{SSC}(1 \times \mathrm{SSC}$ is $0.15 \mathrm{M} \mathrm{NaCl}$ plus $0.015 \mathrm{M}$ sodium citrate, $\mathrm{pH} 7.0$ ) containing $20 \%$ formamide as a mock hybridization, rinsed in $2 \times \mathrm{SSC}$, and dried. The DNA was released from the test discs in $1.6 \mathrm{M} \mathrm{HClO}_{4}$ by using the method of Meijs and Schilperoort (17) and was quantified as described by Richards (20).

Cultures of $S$. capsulata $\mathrm{LMG} 2830^{\mathrm{T}}$ and $S$. paucimobilis LMG $1227^{\mathrm{T}}$ were labeled in vivo by adding $\left[{ }^{14} \mathrm{C}\right]$ orotate and $\left[{ }^{3} \mathrm{H}\right]$ adenine, respectively. rRNA was isolated as described by Moore and McCarthy (18). Final purification of rRNA was performed as described by De Ley and De Smedt (7). $R$. suberifaciens $\mathrm{CAl}^{\mathrm{T}}$ was labeled in vivo with $5 \mu \mathrm{Ci}$ of $\left[5,6-{ }^{3} \mathrm{H}\right]$ uridine $(35$ to $50 \mathrm{Ci} / \mathrm{mmol}$ ) per $\mathrm{ml}$ at the beginning of the log phase and twice during exponential growth. Cultures were given unlabeled uridine $(40 \mu \mathrm{mol}) 2 \mathrm{~h}$ before harvesting. RNA was extracted by using the method of Ausubel et al. (1a) and was resuspended in DNase buffer $(20 \mathrm{mM}$ Tris-Cl, $\left.10 \mathrm{mM} \mathrm{MgCl}_{2} ; \mathrm{pH} 8.0\right)$. Residual DNA was removed by treatment with DNase $(300 \mathrm{U} / \mathrm{ml})$ at $37^{\circ} \mathrm{C}$ for $30 \mathrm{~min}$. The RNA was then extracted once with phenol-chloroform (equilibrated in $10 \mathrm{mM}$ Tris- $\mathrm{Cl}$ [pH 8.0]-1 mM EDTA) and twice with chloroform and then precipitated with 0.04 volume of $5.0 \mathrm{M} \mathrm{NaCl}$ and 2.5 volumes of absolute ethanol. Crude RNA was resuspended in gradient buffer $(0.1 \mathrm{M}$ sodium acetate buffer [pH 5.0] containing $0.1 \mathrm{M} \mathrm{NaCl}, 2.0$ $\mathrm{mM}$ EDTA, and $0.2 \%$ diethylpyrocarbonate). Sucrose gradients (10 to $40 \%$ [wt/vol] sucrose in gradient buffer) were loaded with 0.5 to $1.0 \mathrm{mg}$ of RNA and centrifuged at 109,000 $\times g$ for $17 \mathrm{~h}$ at $4^{\circ} \mathrm{C}$. Fractions were collected and measured for radioactivity, and the fractions containing $23 \mathrm{~S}$ and $16 \mathrm{~S}$ RNAs were dialyzed against an excess of $2 \times \mathrm{SSC}$ at $4^{\circ} \mathrm{C}$ and stored at $-20^{\circ} \mathrm{C}$. Fractions containing $23 \mathrm{~S}$ and $16 \mathrm{~S}$ RNAs were identified by electrophoresis on a $1.0 \%$ agarose gel in $1 \times$ MOPS buffer ( $20 \mathrm{mM}$ MOPS [morpholinepropanesulfonic acid], 5.0 mM sodium acetate, $2.0 \mathrm{mM}$ EDTA) against known 23S and 16S rRNA standards. The specific activity of the rRNA was approximately $18,000 \mathrm{dpm} / \mu \mathrm{g}$.

The conditions used for hybridization of rRNA to DNA on filter discs were those described by De Smedt and De Ley (9). Unhybridized rRNA was removed by digesting it with RNase $\mathrm{A}$ at $37^{\circ} \mathrm{C}$ for $1 \mathrm{~h}$. The RNase was prepared by dissolving $100 \mathrm{mg}$ of RNase A (code RAF, from bovine pancreas; Worthington Biochemical Corp., Freehold, N.J.) in a beaker containing $75 \mathrm{ml}$ of water, $1.753 \mathrm{~g}$ of $\mathrm{NaCl}$, and $0.630 \mathrm{~g}$ of citric acid ( $\mathrm{pH} 3.0$ ), boiling the resulting preparation for $5 \mathrm{~min}$, and chilling it on ice. At room temperature, the $\mathrm{pH}$ was adjusted to 7.0 with $\mathrm{NaOH}$, and the volume brought up to $100 \mathrm{ml}$ with preboiled water. The concentration of RNase used was determined in a preliminary hybridization experiment performed with a reference strain for which the DNA-rRNA melting temperature was known. After the unhybridized rRNA was removed, discs were rinsed twice in $50 \mathrm{ml}$ of $2 \times \mathrm{SSC}$ at room temperature. Each disc was put through a temperature gradient consisting of $5^{\circ} \mathrm{C}$ increments from 50 to $90^{\circ} \mathrm{C}$ in $2 \mathrm{ml}$ of $1.5 \times \mathrm{SSC}-20 \%$ formamide in scintillation vials (9). A 10 -ml portion of scintillation cocktail (Bio-Safe; Research Products Corp., Mount Prospect, Ill.) was added to each vial, and the amount of rRNA released at each temperature was calculated from the radioactive counts determined by liquid scintillation counting for $20 \mathrm{~min}$ with a model LS 7500 instrument (Beckman Instruments, Inc., Fullerton, Calif.).

Melting profiles were determined for each hybrid at least four times with rRNA from $R$. suberifaciens $\mathrm{CA1}^{\mathbf{T}}$ and two times with rRNAs from $S$. capsulata LMG $2830^{\mathrm{T}}$ and $S$. paucimobilis LMG $1227^{\mathrm{T}}$. Melting temperatures were defined as the temperatures at which $50 \%$ of the radioactivity was removed from the filters. A dendrogram was constructed for the Rhizomonas, Sphingomonas, and Zymomonas species on the basis of the melting temperatures for hybrids with rRNAs from $R$. suberifaciens, $S$. capsulata, $S$. paucimobilis, and Zymomonas mobilis (12).

rDNA sequencing. DNAs corresponding to $16 \mathrm{~S}$ rRNAs (rDNAs) of all of the Rhizomonas and Sphingomonas strains mentioned above were amplified by the polymerase chain reaction (PCR), using a model 480 DNA thermal cycler (Perkin Elmer Corp., Norwalk, Conn.). For comparison, rDNA of Agrobacterium tumefaciens was also included. Chromosomal DNA was extracted as described by van Bruggen et al. (27) and was quantified spectrophotometrically at $260 \mathrm{~nm}$. Two oligodeoxynucleotides with sequences similar to those of conserved regions of $16 \mathrm{~S}$ rRNA at positions 9 to 29 (oligo 6) (14a) and positions 519 to 536 (primer A) (15) of Escherichia coli (28) were used as PCR primers. Oligo 6 (5'-GAGTTTGATCCTGGCTCAGGA) was synthesized by the DNA Synthesis Facility, Department of Biochemistry, University of California, Berkeley. Primer A (5'-TATTACCGCGGCTGCTG) was obtained from Operon Technologies, Inc., Alameda, Calif. The PCR was carried out in a reaction volume of $33 \mu \mathrm{l}$ containing 1 to $2 \mathrm{ng}$ of bacterial DNA, $1 \mu \mathrm{mol}$ of each primer, $1 \mathrm{U}$ of Taq polymerase (Promega Corp., Madison, Wis.), $50 \mathrm{mM} \mathrm{KCl}, 1.5$ $\mathrm{mM} \mathrm{MgCl}, 10 \mathrm{mM}$ Tris (pH 8.3), and dideoxynucleotide triphosphates at concentrations of $200 \mu \mathrm{M}$. A total of 25 amplification cycles were used. The PCR conditions con- 
sisted of denaturation at $95^{\circ} \mathrm{C}$ for $1.5 \mathrm{~min}$, primer annealing at $55^{\circ} \mathrm{C}$ for $2 \mathrm{~min}$, and chain extension at $72^{\circ} \mathrm{C}$ for $2 \mathrm{~min}$. Amplified DNA was purified from agarose gels with Gene Clean (Bio 101, Inc., La Jolla, Calif.), precipitated with ethanol-sodium acetate $(100 \%$ ethanol-3 M sodium acetatewater, 950:40:10), and resuspended in sterile TE (10 mM Tris-HCl, 1.0 mM EDTA; pH 8.0).

Sequencing reactions were carried out with the ds DNA Cycle Sequencing System (Bethesda Research Laboratories, Life Technologies, Inc., Gaithersburg, Md.) according to the manufacturer's instructions, using the PCR-amplified DNA as the template and oligo 6 as the sequencing primer. The PCR sequencing program consisted of 20 cycles of denaturation at $95^{\circ} \mathrm{C}$ for $45 \mathrm{~s}$, primer annealing at $55^{\circ} \mathrm{C}$ for $5 \mathrm{~s}$, and chain extension at $72^{\circ} \mathrm{C}$ for $30 \mathrm{~s}$. Reaction products were electrophoresed in a $6 \%$ polyacrylamide gel containing $8 \mathrm{M}$ urea in $1 \times$ TBE buffer $(0.089 \mathrm{M}$ Tris-borate, $0.089 \mathrm{M}$ boric acid, $0.004 \mathrm{M}$ EDTA). Sequencing gels were dried on filter paper at $80^{\circ} \mathrm{C}$ under a vacuum and were exposed to $\mathrm{X}$-ray film.

Sequence data were aligned and pairwise similarities were calculated by using the GCG program (Genetics Computer Group, University of Wisconsin, Madison) on a VAX mainframe computer. Phylogenetically conserved positions were deleted, and variable region sequences were subjected to cluster analysis by using the parsimony and bootstrapping methods (MacIntosh version 3.0L of PAUP [22]). Agrobacterium tumefaciens was used as the outgroup organism.

DNA-DNA hybridization. DNAs from $R$. suberifaciens $\mathrm{CA1}^{\mathrm{T}}$, Rhizomonas sp. strain WI4, and $S$. paucimobilis ATCC $29837^{\mathrm{T}}$ were hybridized with DNAs from five strains of $R$. suberifaciens, Rhizomonas sp. strain WI4, and nine strains of Sphingomonas spp.

Chromosomal DNA was extracted as described by van Bruggen et al. (27). DNA was quantified spectrophotometrically at $260 \mathrm{~nm}$. DNA from each strain was denatured in 0.4 $\mathrm{M} \mathrm{NaOH}-10 \mathrm{mM}$ EDTA, and $1.0-\mu \mathrm{g}$ portions were transferred onto Zeta-probe membranes (Bio-Rad Laboratories, Richmond, Calif.) or Hybond $\mathrm{N}^{+}$membranes (Amersham, Arlington Heights, Ill.) with a slot blot vacuum manifold (model Minifold II; Schleicher and Schuell, Keene, N.H.). The blots were washed with $0.4 \mathrm{M} \mathrm{NaOH}$ and rinsed in $2 \times$ SSC as described previously (27), air dried, and fixed at $80^{\circ} \mathrm{C}$ in a vacuum oven for 1 to $2 \mathrm{~h}$. DNA from $R$. suberifaciens $\mathrm{CA}^{\mathrm{T}}$, Rhizomonas sp. strain WI4, or $S$. paucimobilis ATCC $29837^{\mathrm{T}}$ was denatured in a boiling water bath for $5 \mathrm{~min}$ and labeled with $\left[{ }^{32} \mathrm{P}\right] \mathrm{dCTP}$ by using an oligolabeling kit (Random Primed DNA Labeling Kit; Boehringer Mannheim). Unincorporated nucleotides were removed by passing the mixture through Sephadex G-50 filters. Slot blots were prehybridized overnight (27). Denatured, labeled probe was added to the blots, and the preparations were hybridized for 15 to $20 \mathrm{~h}$ at $50^{\circ} \mathrm{C}$ (moderately stringent conditions). The blots were washed and rinsed as described previously (27), blotted, and autoradiographed with type XAR5 film (Kodak, Rochester, N.Y.). The extent of hybridization was determined by directly measuring the counts per minute on the blots, using a Radioanalytic Imaging System (Ambis Systems, Inc., San Diego, Calif.). There were three replications for each strain randomized on several blots.

\section{RESULTS}

The melting temperatures of hybrids between $R$. suberifaciens $\mathrm{CA}^{\mathrm{T}}$ rRNA and DNAs from $R$. suberifaciens strains ranged between 78 and $80.5^{\circ} \mathrm{C}$ (Table 1). Hybrids with $S$. yanoikuyae DNA melted at $75^{\circ} \mathrm{C}$, and hybrids with Rhizomonas sp. strain WI4, Z. mobilis, $S$. paucimobilis, and $S$. capsulata DNAs melted at 70 to $72^{\circ} \mathrm{C}$. The melting temperatures of hybrids with DNAs from other members of superfamily IV ranged from 63 to $66^{\circ} \mathrm{C}$. The melting temperatures of hybrids with DNA from Agromonas oligotrophica, which was not classified in a superfamily but contained ubiquinone Q10, fell in the same range as the melting temperatures of hybrids with DNAs from strains belonging to superfamily IV. The melting temperatures of hybrids with DNAs from strains belonging to superfamilies II and III ranged from 59 to $61^{\circ} \mathrm{C}$ (Table 1 ).

Hybrids of $S$. paucimobilis rRNA with DNAs from $S$. paucimobilis, $S$. parapaucimobilis, and Sphingomonas genospecies I and II had melting temperatures between 79 and $80.6^{\circ} \mathrm{C}$ (Table 1), while hybrids with DNAs from $S$. capsulata and Sphingomonas adhaesiva melted at 71.1 and $75.2^{\circ} \mathrm{C}$, respectively. The melting temperatures of hybrids with DNAs from $Z$. mobilis and Rhizomonas spp. were similar to the melting temperatures of hybrids with $S$. capsulata DNA. For hybrids of rRNA from $S$. capsulata, the melting temperatures were $80^{\circ} \mathrm{C}$ with $S$. capsulata DNA and between 71 and $73^{\circ} \mathrm{C}$ with DNAs from strains belonging to other Sphingomonas spp., Z. mobilis, and Rhizomonas spp.

The results are shown in a melting temperature dendrogram in Fig. 1. The following four closely related but separate rRNA branches in superfamily IV can be distinguished: one branch for the genus Zymomonas, one branch for $S$. capsulata, one branch for other Sphingomonas spp., and one branch for $R$. suberifaciens and $S$. yanoikuyae. Rhizomonas sp. strain WI4 is located at the base of the Rhizomonas branch.

DNA hybridization with DNAs from $R$. suberifaciens $\mathrm{CA1}^{\mathrm{T}}$, Rhizomonas sp. strain WI4, and $S$. paucimobilis ATCC $29837^{\mathrm{T}}$ confirmed that strains FL2, FL3, NY12, and WI3 belong to the genus Rhizomonas, while strain WI4 is as closely related to the genus Rhizomonas as to the genus Sphingomonas (Table 2). S. yanoikuyae exhibited higher levels of DNA hybridization with Rhizomonas sp. strain WI4 and $S$. paucimobilis ATCC $29837^{\mathrm{T}}$ than with $R$. suberifaciens $\mathrm{CAl}^{\mathrm{T}}$. The levels of DNA hybridization with $S$. paucimobilis were higher for Sphingomonas genospecies I and II, Sphingomonas parapaucimobilis, and $S$. adhaesiva than for $S$. capsulata.

rDNA sequencing with primer oligo 6 resulted in a 270base sequence (Fig. 2), corresponding to positions 50 to 350 of Escherichia coli rRNA (28). Compared with $E$. coli rRNA, 30 bases were deleted. The 270 -base sequences displayed enough variability to clearly distinguish three main clusters, one for $S$. capsulata, one for all other species of the genus Sphingomonas except $S$. yanoikuyae, and one for $R$. suberifaciens, Rhizomonas sp. strains WI4 and CA16, and $S$. yanoikuyae (Fig. 2 and 3). One base in particular, corresponding to position 52 of $E$. coli rRNA in a relatively conserved region, helped to separate the last three strains in a subgroup of the Rhizomonas cluster (Fig. 3).

\section{DISCUSSION}

The melting temperatures of hybrids between $R$. suberifaciens $C A 1^{\mathrm{T}}$ rRNA and DNAs from various strains belonging to superfamilies II, III, and IV indicated that $R$. suberifaciens is a member of superfamily IV. Within this superfamily, strains of $R$. suberifaciens constitute a separate branch which is closely related to the rRNA branch contain- 
ing Zymomonas spp. and the rRNA branch containing Sphingomonas spp., which includes $S$. paucimobilis, $S$. parapaucimobilis, $S$. adhaesiva, and two Sphingomonas genospecies (29). Both the rRNA-DNA hybridization data and the rDNA sequences of $S$. capsulata showed that $S$. capsulata does not belong to the Sphingomonas rRNA branch and needs to be transferred to a new genus.

A close relationship between the genera Rhizomonas and Sphingomonas was postulated previously on the basis of similar fatty acid compositions, various physiological test results, and relatively high levels of DNA-DNA hybridization between $R$. suberifaciens $\mathrm{CA1}^{\mathrm{T}}$ and $S$. paucimobilis under moderately stringent conditions (27). At that time, we considered the possibility of transferring $S$. paucimobilis (then $P$. paucimobilis) to the newly proposed genus $R h i$ zomonas (27). However, the levels of hybridization between

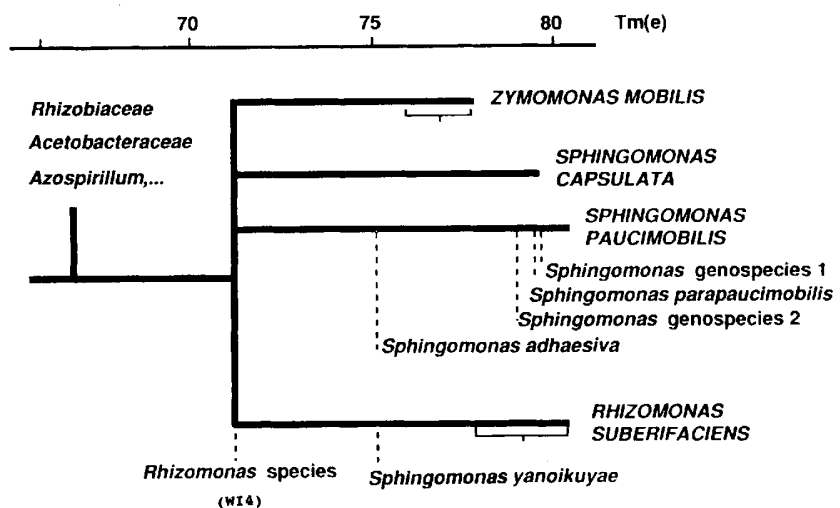

FIG. 1. Meiting temperature $\left[\mathrm{T}_{m(e)}\right]$ dendrogram showing the Zymomonas, $S$. capsulata, $S$. paucimobilis, and $R$. suberifaciens rRNA branches in rRNA superfamily IV.

TABLE 1. Bacterial strains used in this study and mean melting temperatures for hybrids between chromosomal DNAs from the strains and rRNAs from $R$. suberifaciens CA1 ${ }^{\mathrm{T}}, S$. paucimobilis LMG $1227^{\mathrm{T}}$, and $S$. capsulata $\mathrm{LMG} 2830^{\mathrm{T}}$

\begin{tabular}{|c|c|c|c|c|c|c|c|}
\hline \multirow{2}{*}{$\begin{array}{l}\text { Super- } \\
\text { family }\end{array}$} & \multirow[b]{2}{*}{ Taxon } & \multirow[b]{2}{*}{ Strain } & \multirow[b]{2}{*}{ Source $^{a}$} & \multirow{2}{*}{$\begin{array}{c}\text { Mean } \\
\mathbf{G}+\mathbf{C} \\
\text { content } \\
(\text { mol\%) }\end{array}$} & \multicolumn{3}{|c|}{ Melting temp $\left({ }^{\circ} \mathrm{C}\right)$ for hybrid with rRNA from: } \\
\hline & & & & & $\begin{array}{l}\text { R. suberifaciens } \\
\mathrm{CA1}^{\mathrm{T}}\end{array}$ & $\begin{array}{l}\text { S. paucimobilis } \\
\text { LMG } 1227^{\mathrm{T}}\end{array}$ & $\begin{array}{l}\text { S. capsulata } \\
\text { LMG } 2830^{\mathrm{T}}\end{array}$ \\
\hline \multirow[t]{32}{*}{ IV } & \multirow[t]{5}{*}{ R. suberifaciens } & NY12 (= LMG 9835) & van Bruggen & 59.4 & 80.5 & & \\
\hline & & FL2 (= LMG 9831) & van Bruggen & 57.9 & 80.0 & 71.2 & 72.4 \\
\hline & & $\mathrm{CA1}^{\mathrm{T}}\left(=\right.$ LMG $\left.9830^{\mathrm{T}}\right)$ & van Bruggen & 58.0 & 79.6 & 71.2 & 73.0 \\
\hline & & FL3 (= LMG 9832) & van Bruggen & 59.4 & 78.1 & 70.4 & 71.7 \\
\hline & & W13 (= LMG 9837) & van Bruggen & 58.9 & 78.0 & & \\
\hline & S. yanoikuyae & LMG $11252^{\mathrm{T}}\left(=\right.$ CCUG $\left.28380^{\mathrm{T}}\right)$ & CCUG & 63.7 & 75.3 & 72.2 & \\
\hline & Rhizomonas sp. & WI4 (= LMG 11032) & van Bruggen & 62.9 & 72.4 & 70.7 & 72.6 \\
\hline & \multirow{2}{*}{ S. capsulata } & LMG $2830^{\mathrm{T}}\left(=\right.$ ATCC $\left.14666^{\mathrm{T}}\right)$ & LMG & 65.9 & & 71.1 & 79.8 \\
\hline & & ATCC $14666^{\mathrm{T}}$ & ATCC & & 71.5 & & \\
\hline & \multirow[t]{2}{*}{ S. paucimobilis } & LMG $1227^{\mathrm{T}}\left(=\right.$ ATCC $\left.29837^{\mathrm{T}}\right)$ & LMG & 65.4 & & 80.6 & 72.4 \\
\hline & & ATCC $29837^{\mathrm{T}}$ & ATCC & & 71.1 & & \\
\hline & S. adhaesiva & LMG $10922^{\mathrm{T}}\left(=\right.$ CCUG $\left.27290^{\mathrm{T}}\right)$ & CCUG & 67.9 & 71.9 & 75.2 & \\
\hline & S. parapaucimobilis & LMG $10923^{\mathrm{T}}\left(=\right.$ CCUG $\left.27291^{\mathrm{T}}\right)$ & CCUG & 66.9 & 72.0 & 79.5 & \\
\hline & Sphingomonas genospecies I & LMG 10925 (= CCUG 27654) & CCUG & 66.2 & 70.3 & 79.7 & \\
\hline & Sphingomonas genospecies II & LMG 10924 (= CCUG 27293) & CCUG & 65.2 & 70.5 & 79.0 & \\
\hline & \multirow{2}{*}{ Z. mobilis subsp. mobilis } & LMG $405^{\mathrm{T}}$ & LMG & & 70.8 & 70.5 & \\
\hline & & LMG 445 & LMG & 48.8 & & & 72.8 \\
\hline & Z. mobilis subsp. pomaceae & LMG $448^{\mathrm{T}}$ & LMG & 48.2 & 70.1 & 69.3 & \\
\hline & Ochrobactrum anthropi & NCTC $12168^{\mathrm{T}}$ & NCTC & 57.2 & 66.4 & & \\
\hline & Beijerinckia indica & ATCC $9039^{\mathrm{T}}$ & ATCC & 56.4 & 66.0 & & 67.2 \\
\hline & Rhizobium meliloti & $8 \mathrm{D} 15$ & Kado & & 65.5 & & \\
\hline & Xanthobacter autotrophicus & ATCC 35674 & ATCC & 67.3 & 65.5 & & 66.5 \\
\hline & Azorhizobium caulinodans & ATCC 43989 & ATCC & & 65.3 & & \\
\hline & \multirow[t]{2}{*}{ Pseudomonas diminuta } & 501 & Baumann & & 65.2 & & \\
\hline & & LMG $1793^{\mathrm{T}}$ & LMG & 65.9 & & & 62.9 \\
\hline & $\begin{array}{l}\text { Gluconobacter oxydans } \\
\text { subsp. sphaericus }\end{array}$ & ATCC 33280 & ATCC & 56.3 & 64.4 & & 62.9 \\
\hline & Agrobacterium tumefaciens & C-58 (= LMG 287) & Kado & & 64.0 & & \\
\hline & $\begin{array}{l}\text { Phyllobacterium myrsi- } \\
\text { nacearum }\end{array}$ & ATCC 43590 & ATCC & 60.3 & 63.7 & & 67.3 \\
\hline & Agrobacterium rhizogenes & 3D1 (= ICPB TR108) & Kado & & 63.4 & & \\
\hline & Bradyrhizobium japonicum & ATCC $10324^{\mathrm{T}}\left(=\mathrm{LMG} 6138^{\mathrm{T}}\right)$ & ATCC & 64.0 & 63.4 & & \\
\hline & Aquaspirillum itersonii & NCIB 9017 & NCIB & 61.8 & & & 65.8 \\
\hline & Agromonas oligotrophica & ATCC 43045 & ATCC & 65.0 & 63.2 & 64.5 & \\
\hline \multirow[t]{3}{*}{ II } & $\begin{array}{l}\text { Pseudomonas fluorescens } \\
\text { biotype A }\end{array}$ & $11 \mathrm{D} 42^{\mathrm{T}}\left(=\operatorname{ATCC} 13525^{\mathrm{T}}\right)$ & Kado & & 60.7 & & \\
\hline & $\begin{array}{l}\text { Xanthomonas campestris pv. } \\
\text { campestris }\end{array}$ & 2D511 & Kado & & 60.6 & & \\
\hline & $\begin{array}{l}\text { Pseudomonas syringae pv. } \\
\text { syringae }\end{array}$ & 5D4214 & Kado & & 60.2 & & \\
\hline III & Pseudomonas cepacia & 23D4 & Kado & & 59.1 & & \\
\hline
\end{tabular}

${ }^{a}$ ATCC, American Type Culture Collection, Rockville, Md.; Baumann, P. Baumann, Department of Microbiology, University of California, Davis; CCUG, Culture Collection of the University of Goteborg, Goteborg, Sweden; Kado, C. I. Kado, Department of Plant Pathology, University of California, Davis; LMG, Collection of the Laboratory of Microbiology, University of Ghent, Ghent, Belgium; NCIB, National Collection of Industrial Bacteria, Aberdeen, Scotland; NCTC, National Collection of Type Cultures, London, England; van Bruggen, A. H. C. van Bruggen, Department of Plant Pathology, University of California, Davis. 
TABLE 2. Mean percentages of DNA homology between chromosomal DNAs from various strains of gram-negative bacteria and DNAs from $R$. suberifaciens $\mathrm{CA1}{ }^{\mathrm{T}}$, Rhizomonas sp. strain WI4, and $S$. paucimobilis ATCC $29837^{\mathrm{T}}$

\begin{tabular}{|c|c|c|c|c|}
\hline \multirow[b]{2}{*}{ Taxon } & \multirow[b]{2}{*}{ Strain } & \multicolumn{3}{|c|}{$\%$ of DNA homology with DNA from: } \\
\hline & & $\begin{array}{l}\text { R. suberifaciens } \\
\mathrm{CA1}^{\mathrm{T}}\end{array}$ & $\begin{array}{l}\text { Rhizomonas sp. } \\
\text { strain WI4 }\end{array}$ & $\begin{array}{l}\text { S. paucimobilis } \\
{\text { ATCC } 29837^{\mathrm{T}}}^{\mathrm{T}}\end{array}$ \\
\hline \multirow[t]{5}{*}{ R. suberifaciens } & $\mathrm{CA1}^{\mathrm{T}}$ & 99.9 & 9.7 & 9.4 \\
\hline & NY12 & 69.3 & 7.8 & 8.9 \\
\hline & FL2 & 75.5 & 8.3 & 8.8 \\
\hline & FL3 & 62.9 & 7.6 & 8.4 \\
\hline & WI3 & 74.4 & 8.3 & 7.7 \\
\hline Rhizomonas sp. & WI4 & 10.8 & 100.0 & 12.8 \\
\hline S. adhaesiva & LMG $10922^{\mathrm{T}}$ & 4.9 & 10.0 & 32.6 \\
\hline \multirow[t]{2}{*}{ S. capsulata } & LMG $2830^{\mathrm{T}}$ & 6.9 & 7.4 & 17.8 \\
\hline & ATCC $14666^{\mathrm{T}}$ & 2.3 & 5.1 & 12.0 \\
\hline Sphingomonas genospecies I & LMG 10925 & 4.9 & 9.1 & 51.2 \\
\hline Sphingomonas genospecies II & LMG 10924 & 4.5 & 9.4 & 51.3 \\
\hline S. parapaucimobilis & LMG $10923^{\mathrm{T}}$ & 5.1 & 7.1 & 59.3 \\
\hline \multirow[t]{2}{*}{ S. paucimobilis } & LMG $1227^{\mathrm{T}}$ & 4.9 & 8.5 & 114.0 \\
\hline & ATCC $29837^{\mathrm{T}}$ & 3.7 & 6.5 & 96.8 \\
\hline S. yanoikuyae & LMG $11252^{\mathrm{T}}$ & 5.9 & 16.1 & 23.3 \\
\hline
\end{tabular}

DNA from $R$. suberifaciens $\mathrm{CA1}^{\mathrm{T}}$ and DNA from $R$ hizomonas sp. strain WI4 or $S$. paucimobilis were much lower in the present study than reported previously (27), despite similar hybridization conditions. This difference proved to be due to a change in the method used for quantifying the radioactive signals (a radioanalytic imaging system instead of densitometry of autoradiographed blots) $(13 \mathrm{a}, 26)$. The low levels of DNA hybridization between $R$. suberifaciens and $S$. paucimobilis and the differences in the melting temperatures of DNA-rRNA hybrids and in the rDNA sequences in this study showed that the members of the $S$. paucimobilis rRNA branch and the members of the Rhizomonas rRNA branch differ enough to warrant two separate genera. Nevertheless, within superfamily IV, these genera are very closely related and differ from other genera in this superfamily primarily in that their outer membranes contain 2-hydroxylated myristic acid rather than the 3-hydroxylated fatty acids that occur in other gram-negative bacteria $(14,27)$.

The melting temperatures of hybrids between Rhizomonas sp. strain WI4 DNA and $R$. suberifaciens strain CA1 ${ }^{\mathrm{T}}$ rRNA

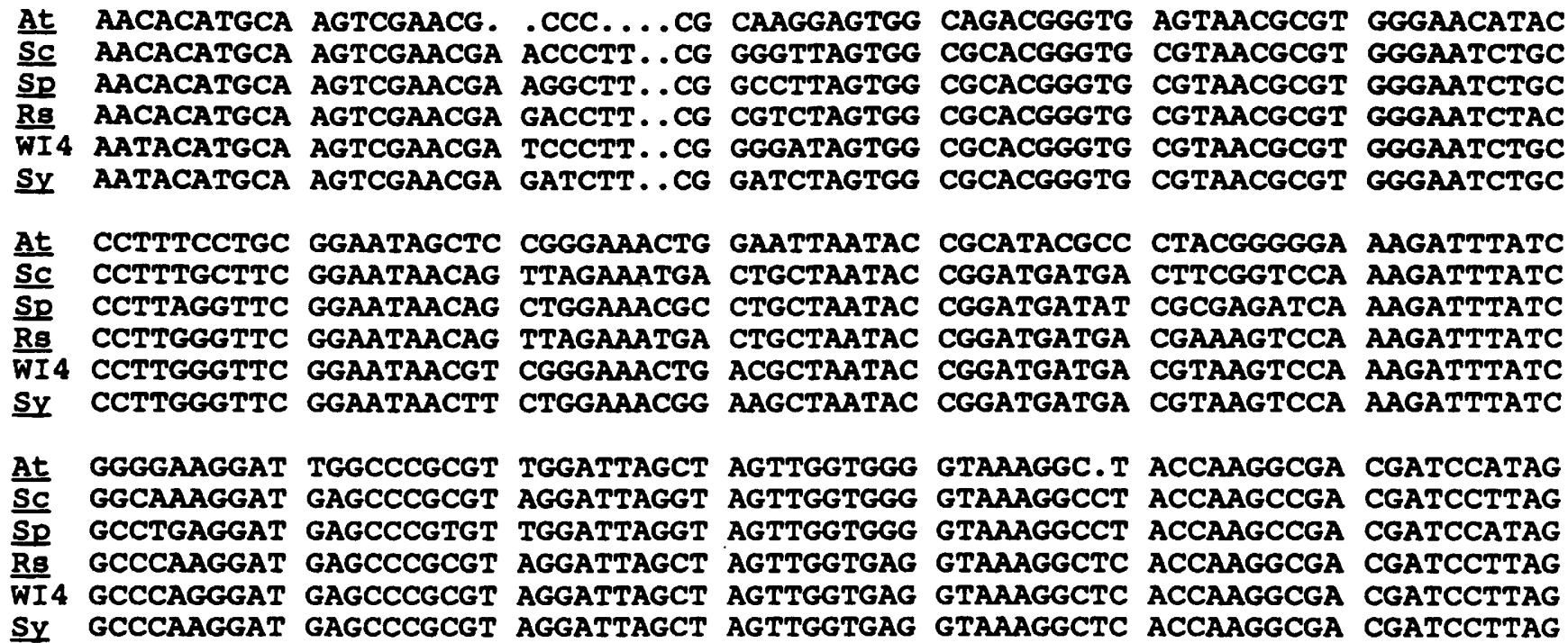

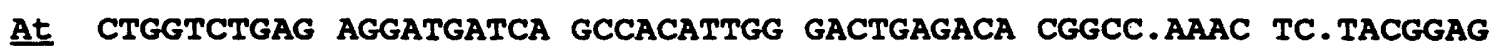

$\underline{\text { SC }}$ CTGGTCTGAG AGgATGATCA GCCACACTGG GACTGAGACA CGGCCCAGAC TCCTACGGAG

Sp CTGGTCT.AG AGGATGATCA GCCACACTGG GACTGAGACA CGGCCCAGAC TCCTACGGAG

Rs CTGGTCTGAG A.GATGATCA GCCACACT.G GACTGAGACA C.G.CCAGAC TC.TACGG.G

WI4 CTGGTCTGAG AGGATCATCA GCCACACTGG GACTGAGACA CG.CCCAGAC TCCTACGGAG Sy CTGGTCTGAg AgGATGATCA GCCACACTGG GACTGAgACA CGgCCCAGAC TCCTACGGAG

FIG. 2. rDNA sequences for Agrobacterium tumefaciens C-58 (At), S. capsulata LMG $2830^{\mathrm{T}}(S c), S$. paucimobilis LMG $1227^{\mathrm{T}}(S p), R$. suberifaciens $\mathrm{CA1}^{\mathrm{T}}(R s)$, Rhizomonas sp. strain WI4 (WI4), and $S$. yanoikuyae LMG $11252^{\mathrm{T}}$ (Sy), corresponding to positions 50 to 350 of $E$. coli rRNA. 


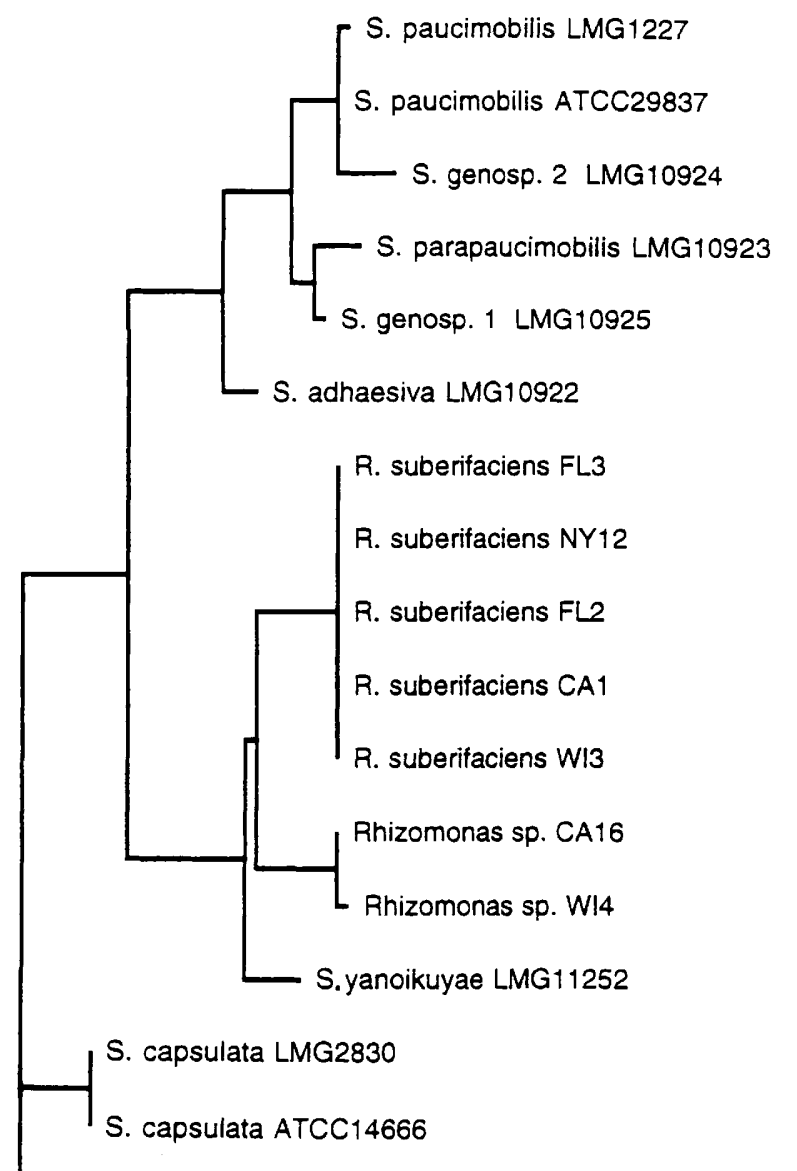

FIG 3 Dendrogram determined by parsimony and bootstrapping, using 270-bp rDNA sequences (Fig. 2). The data are derived from $R$. suberifaciens $\mathrm{CA}^{\mathrm{T}}$, FL2, FL3, NY12, and W13, Rhizomonas sp. strains WI4 and CA16, S. yanoikuyae LMG $11252^{\mathrm{T}}$, Sphingomonas genospecies I strain LMG 10925, Sphingomonas genospecies II strain LMG 10924, $S$. paucimobilis LMG $1227^{\mathrm{T}}$ and ATCC $29837^{\mathrm{T}}, S$. adhaesiva LMG $10922^{\mathrm{T}}$, S. parapaucimobilis LMG $10923^{\mathrm{T}}$, and $S$. capsulata LMG $2830^{\mathrm{T}}$ and ATCC $14666^{\mathrm{T}}$. Agrobacterium tumefaciens $\mathrm{C}-58$ was used as an outgroup.

were similar to the melting temperatures of hybrids between DNAs from Sphingomonas strains and strain $\mathrm{CA1}^{\mathrm{T}}$ rRNA. This indicates that, genetically, strain WI4 is as far removed from $R$. suberifaciens as it is from Sphingomonas species. However, additional hybridizations with rRNAs from $S$. capsulata LMG $2830^{\mathrm{T}}$ and $S$. paucimobilis LMG $1227^{\mathrm{T}}$ showed that strain WI4 does not belong to the rRNA branches of these species. Although the melting temperatures of DNA-rRNA hybrids indicate that strain WI4 could occupy a separate position equidistant from the genus Sphingomonas and $R$. suberifaciens, a phylogenetic analysis of rDNA sequences suggested that strain WI4 is more closely related to $R$. suberifaciens than to Sphingomonas species. Final classification of strain WI4 will require more polyphasic studies that include other closely related isolates.

On the basis of the melting temperature of the hybrid between $S$. yanoikuyae LMG $11252^{\mathrm{T}}$ DNA and $R$. suberifaciens CA1 $1^{\mathrm{T}}$ rRNA $\left(75.3^{\circ} \mathrm{C}\right), S$. yanoikuyae belongs on the $R$. suberifaciens $\mathrm{rRNA}$ branch and genotypically can be considered a member of the genus Rhizomonas. This was confirmed by the results of a phylogenetic analysis of rDNA sequences. The sequences of $S$. yanoikuyae rRNA were more similar to the sequences of Rhizomonas sp. strain WI4 and CA16 rRNAs than to the sequences of rRNAs from $R$. suberifaciens strains. However, the levels of DNA-DNA hybridization with $R$. suberifaciens $\mathrm{CAl}^{\mathrm{T}}$ and Rhizomonas sp. strain WI4 were not high enough to consider $S$. yanoikuyae a member of either of these Rhizomonas taxa. More genetic and physiological studies will be needed to classify $S$. yanoikuyae as a species of the genus Rhizomonas.

This was the first study which showed that rDNA sequences corresponding to positions 50 through 350 of $E$. coli rRNA (28) could be used to separate strains of the genus Rhizomonas from Sphingomonas strains and strains of a potentially new genus containing $S$. capsulata. Moreover, these sequences contained enough variability to distinguish among several Rhizomonas and Sphingomonas species. Yabuuchi et al. (29) used rRNA sequences corresponding to positions 1220 through 1376 of $E$. coli $16 \mathrm{~S}$ rRNA with primer C of Lane et al. (15) to initiate the sequences. A phylogenetic analysis of those sequences resulted in good separation of $S$. paucimobilis, S. adhaesiva, $S$. yanoikuyae, and $S$. capsulata, but not of $S$. paucimobilis, $S$. parapaucimobilis, and Sphingomonas genospecies I and II (29). These last four species had slightly different rDNA sequences in our study. The grouping obtained by Yabuuchi et al. (29) generally agreed with our grouping except for the placement of $S$. capsulata and S. yanoikuyae strains; on the basis of our results, these strains may belong to an unnamed genus and the genus Rhizomonas, respectively. If Rhizomonas strains had been included in the study of Yabuuchi et al., $S$. yanoikuyae might have clustered in the Rhizomonas group. Additional phylogenetic, biochemical, and physiological studies are currently under way to characterize and describe several new Rhizomonas species (25a).

\section{ACKNOWLEDGMENTS}

We thank C. I. Kado and P. Baumann for supplying bacterial cultures. We are very grateful to $B$. Kirkpatrick for advice on sequencing of rDNA and for supplying primer oligo 6 .

Most of this work was supported by the California Iceberg Lettuce Research Board. M.G. is indebted to the National Fund for Medical Scientific Research, Belgium, for research and personnel grants.

\section{REFERENCES}

1. American Type Culture Collection. 1989. Catalogue for bacteria and phages. American Type Culture Collection, Rockville, Md.

1a.Ausubel, F. M., R. Brent, R. E. Kingston, D. D. Moore, J. G. Seldman, J. A. Smith, and K. Struhl. 1987. Current protocols in molecular biology, p. 4.4.2-4.4.4. John Wiley and Sons, New York.

2. Bally, R., D. Thomas-Bauzon, T. Heulin, J. Balandreau, C. Richard, and J. De Ley. 1983. Determination of the most frequent $\mathrm{N}_{2}$-fixing bacteria in a rice rhizosphere. Can. J. Microbiol. 29:881-887.

3. Bauwens, M., and J. De Ley. 1981. Improvements in the taxonomy of Flavobacterium by DNA:rRNA hybridizations, p. 27-31. In H. Reichenbach and O. B. Weeks (ed.), The Flavobacterium-Cytophaga group. Proceedings of the International Symposium on Yellow-Pigmented Gram-Negative Bacteria of the Flavobacterium-Cytophaga Group. Gesellschaft fuer Biotechnologische Forschung mbH, Braunschweig-Stoeckheim, Germany.

4. Collins, M. D., and D. Jones. 1981. Distribution of isoprenoid quinone structural types in bacteria and their taxonomic implications. Microbiol. Rev. 45:316-354.

5. Datnoff, L. E., and R. T. Nagata. 1990. Isolation of Rhizomonas suberifaciens in Florida. Plant Dis. 74:394. 
6. Dees, S. B., C. W. Moss, R. E. Weaver, and D. Hollis. 1979. Cellular fatty acid composition of Pseudomonas paucimobilis and groups IIk-2, Ve-1, and Ve-2. J. Clin. Microbiol. 10:206209.

7. De Ley, J., and J. De Smedt. 1975. Improvements of the membrane filter method for DNA:rRNA hybridization. Antonie van Leeuwenhoek 41:287-307.

8. De Ley, J., and R. Tijtgat. 1970 . Evaluation of membrane filter methods for DNA-DNA hybridization. Antonie van Leeuwenhoek J. Microbiol. Serol. 36:461-474.

9. De Smedt, J., and J. De Ley. 1977. Intra- and intergeneric similarities of Agrobacterium ribosomal ribonucleic acid cistrons. Int. J. Syst. Bacteriol. 27:222-240.

10. De Vos, P., and J. De Ley. 1983. Intra- and intergeneric similarities of Pseudomonas and Xanthomonas ribosomal ribonucleic acid cistrons. Int. J. Syst. Bacteriol. 33:485-509.

11. De Vos, P., A. van Landschoot, P. Segers, R. Tytgat, M. Gillis, M. Bauwens, R. Rossau, M. Goor, B. Pot, K. Kersters, P. Lizzaraga, and J. De Ley. 1989. Genotypic relationships and taxonomic localization of unclassified Pseudomonas and Pseudomonas-like strains by deoxyribonucleic acid-ribosomal ribonucleic acid hybridizations. Int. J. Syst. Bacteriol. 39:3549.

12. Gillis, M., and J. De Ley. 1980. Intra- and intergeneric similarities of the ribosomal ribonucleic acid cistrons of Acetobacter and Gluconobacter. Int. J. Syst. Bacteriol. 30:7-27.

13. Holmes, B., R. J. Owen, A. Evans, H. Malnick, and W. R. Willcox. 1977. Pseudomonas paucimobilis, a new species isolated from human clinical specimens, the hospital environment, and other sources. Int. J. Syst. Bacteriol. 27:133-146.

13a.Jochimsen, K. N. Unpublished data.

14. Kawahara, K., U. Seydel, M. Matsuura, H. Danbara, E. T. Rietchel, and U. Zaehringer. 1991. Chemical structure of glycosphingolipids isolated from Sphingomonas paucimobilis. FEBS Lett. 292:107-110.

14a.Kirkpatrick, B. Personal communication.

15. Lane, D. J., B. Pace, G. J. Olsen, D. A. Stahl, M. L. Sogin, and N. R. Pace. 1985. Rapid determination of 16 S ribosomal RNA sequences for phylogenetic analysis. Proc. Natl. Acad. Sci. USA 82:6955-6959.

16. Lucas, R. E., and V. L. Guzman. 1980. The incidence of corky root rot of lettuce due to soil moisture levels, nitrogen sources, and potash rates. A greenhouse study. Belle Glade ARFC Report EV-1980-10. University of Florida, Gainesville.

17. Meijs, W. H., and R. A. Schilperoort. 1971. Determination of the amount of DNA on nitrocellulose membrane filters. FEBS Lett.
12:166-168.

18. Moore, R. L., and B. J. McCarthy. 1967. Comparative study of ribosomal ribonucleic acid cistrons in enterobacteria and myxobacteria. J. Bacteriol. 94:1066-1074.

19. Ohta, H., and T. Hattori. 1983. Agromonas oligotrophica gen. nov., sp. nov., a nitrogen-fixing oligotrophic bacterium. Antonie van Leeuwenhoek 49:429-446.

20. Richards, G. M. 1974. Modifications of the diphenylamine reaction giving increased sensitivity and simplicity in the estimation of DNA. Anal. Biochem. 57:369-376.

21. Stackebrandt, E., R. G. E. Murray, and H. G. Truper. 1988. Proteobacteria classis nov., a name for the phylogenetic taxon that includes the "purple bacteria and their relatives." Int. J. Syst. Bacteriol. 38:321-325.

22. Swofford, D. L. 1990. PAUP: phylogenetic analysis using parsimony. MacIntosh version 3.0L. Illinois Natural History Survey, Champaign.

23. van Bruggen, A. H. C., P. R. Brown, and K. N. Jochimsen. 1989. Corky root of lettuce caused by strains of a gram-negative bacterium from muck soils of Florida, New York, and Wisconsin. Appl. Environ. Microbiol. 55:2635-2640.

24. van Bruggen, A. H. C., R. G. Grogan, C. P. Bogdanoff, and C. M. Waters. 1988. Corky root of lettuce in California caused by a Gram-negative bacterium. Phytopathology 78:1139-1145.

25. van Bruggen, A. H. C., and K. N. Jochimsen. 1992. First report of Rhizomonas sp. causing corky root of lettuce in Europe. Neth. J. Plant Pathol. 98:45-56.

25a.van Bruggen, A. H. C., and K. N. Jochimsen. Unpublished data.

26. van Bruggen, A. H. C., K. N. Jochimsen, A. A. Benedict, and L. W. Pollard. 1992. Monoclonal antibodies for the detection of Rhizomonas suberifaciens, causal agent of corky root of lettuce, with enzyme immunoassays. Food Agric. Immunol. 4:27-40.

27. van Bruggen, A. H. C., K. N. Jochimsen, and P. R. Brown. 1990. Rhizomonas suberifaciens gen. nov., sp. nov., the causal agent of lettuce corky root. Int. J. Syst. Bacteriol. 40:175-188.

28. Woese, C. R., S. Winker, and R. R. Gutell. 1990. Architecture of ribosomal RNA: constraints on the sequence of "tetra-loops." Proc. Natl. Acad. Sci. USA 87:8467-8471.

29. Yabuuchi, E., I. Yano, H. Oyaizu, Y. Hashimoto, T. Ezaki, and H. Yamamoto. 1990. Proposals of Sphingomonas paucimobilis gen. nov. and comb. nov., Sphingomonas parapaucimobilis sp. nov., Sphingomonas yanoikuyae sp. nov., Sphingomonas adhaesiva sp. nov., Sphingomonas capsulata comb. nov., and two genospecies of the genus Sphingomonas. Microbiol. Immunol. 34:99-110. 